\title{
HISTORY OF EDUCATION IN MEDICINE AND SURGERY, FIRST HOSPITALS - DEVELOPMENT OF UROLOGY IN DANZIG/GDAŃSK
}

\author{
HISTORIA SZKOLENIA MEDYCZNEGO I CHIRURGICZNEGO, PIERWSZE \\ SZPITALE - ROZWÓJ UROLOGII W GDAŃSKU (DANZIG)
}

Klaus-Groth-Str. 16, D-45472 Muelheim an der Ruhr, Germany

\section{Streszczenie}

Celem pracy było opisanie rozwoju szpitalnictwa, szkolenia medycznego i powstania urologii w Gdańsku oraz przedstawienie sylwetek znanych chirurgów, zajmujących się szczególnie leczeniem chorób układu moczowo-płciowego. Opisano także początki urologii w okresie powojennym i jej rozwój w ramach Kliniki Chirurgicznej Akademii Medycznej w Gdańsku (AMG), aż do jej pełnego usamodzielnienia oraz powstania Kliniki Urologicznej AMG.

W pracy wykorzystano materiały i dokumentację z bibliotek i archiwów zarówno polskich, jak i niemieckich.

Początki szpitalnictwa w Gdańsku związane są z przybyciem Zakonu Krzyżackiego w 1308 r. Najwcześniejszą instytucją, o której mówią źródła historyczne, był Szpital Świętego Ducha powstały w latach 1310-1311. Szpital był prowadzony przez zakon szpitalników i do $1382 \mathrm{r}$. był przeznaczony dla chorych, sierot, pielgrzymów, podróżnych, starców, kalek i biedaków. $\mathrm{W}$ późniejszych wiekach nastąpił dalszy rozwój szpitalnictwa gdańskiego. Dopiero w XIX w., wraz ze wzrostem liczby mieszkańców miasta, rozwojem nauki i postępem medycyny, istniejący „stary” Szpital Miejski przestał był jedyny, gdyż w Gdańsku wybudowano trzy nowoczesne szpitale: Szpital Położniczo-Ginekologiczny (1819 r.), Najświętszej Marii Panny (1852 r.) oraz Ewangelicki Szpital Diakonistek (1857 r.). W 1911 r. ukończono budowę nowoczesnego Szpitala Miejskiego (Stadtisches Krankenhaus) w Gdańsku.

W 1935 r. na bazie Szpitala Miejskiego otwarto w Wolnym Mieście Gdańsku Akademię Praktycznej Medycyny (Staatliche Academie für Praktische Medizin zu Danzig). Po pięciu latach, w 1940 r., została ona przekształcona w Gdańską Akademię Medyczną (Medizinische Akademie in Danzig - MAD).
Tradycja szkolenia medycznego na poziomie średnim w Gdańsku sięga XV w. Kształcenie medyczne w Gdańsku ma wielowiekową tradycję i zaczęło się w Katedrze Anatomii i Medycyny w Gdańskim Gimnazjum Akademickim (Gymnasium Academicum Sive Illustre). Gimnazjum istniało przez 232 lata, od 1584 do $1812 \mathrm{r}$.

W latach 1454-1820 w Gdańsku istniał Cech Chirurgów. W jego mistrzowskich warsztatach kształcili się adepci tego rzemiosła. Przez wieki terapią manualną zajmowali się także ludzie bez wykształcenia akademickiego, jak balwierze, łaziebnicy i wędrowni chirurdzy.

Do końca 1946 r. nie istniał w Gdańsku samodzielny oddział urologiczny. Operacyjną urologią zajmowali się chirurdzy. W okresie międzywojennym zabiegi i operacje na narządach moczowo-płciowych przeprowadzano na wszystkich oddziałach chirurgicznych.

Koniec II wojny światowej stworzył nową sytuację polityczną w Europie. Gdańsk oraz Pomorze zostały przyznane Polsce. W 1945 r. polski rząd na bazie MAD utworzył Akademię Lekarską w Gdańsku, później dwukrotnie przemianowaną, najpierw na Gdańską Akademię Medyczną (GAM), a w 2009 r. na Gdański Uniwersytet Medyczny.

Dopiero polityczne zmiany po II wojnie światowej przyspieszyły proces separacji (oddzielenia) urologii od chirurgii. W maju 1947 r. przy I Klinice Chirurgicznej (kierownik: prof. Kornel Michejda, 1887-1960, później prof. Stanisław Nowicki, a w końcu prof. Zdzisław Kieturakis) otwarto 30-łóżkowy pododdział urologiczny. Jego kierownikiem został przybyły ze Lwowa (Lemberg) urolog dr Tadeusz Lorenz (1906-1986). Po jego wyjeździe do Wrocławia w 1958 r. dr Jan Renkielski (1913-1996) prowadził ten pododdział do $1971 \mathrm{r}$. 
W 1971 r. oddział przekształcono w samodzielną 39-łóżkową Klinikę Urologii GAM. Kierownikiem jej został docent, później profesor, Kazimierz Adamkiewicz (1928-2004) z Zabrza (Hindenburg). Zorganizował i wyposażył klinikę, doprowadzając ją w krótkim czasie do poziomu nowoczesnych klinik, tak w zakresie naukowym, dydaktycznym, jak i usługowym. W czasie choroby profesora Adamkiewicza i po jego przejściu na rentę klinikę prowadził docent (później profesor) Kazimierz Krajka (*1941). Od czasu przejścia prof. Krajki na emeryturę w 2012 r. kierownikiem Kliniki Urologicznej w Gdańsku jest docent Marcin Matuszewski (*1965).

H a s $\nmid$ a: historia medycyny - historia urologii - Gdańsk Danzig.

\section{Summary}

The aim of the study is to present the development of hospital services and the teaching of medicine, and the development of urology in Danzig (Gdańsk). Well known Danzig surgeons who were interested in surgery of the genitourinary system are also presented. The beginning of urological surgery and its development within the framework of the department of surgery and as an independent facility at the Medical Academy of Gdańsk in the post-war period is also described.

Extensive research was undertaken for the collection of literature and documents in German and Polish archives and libraries in order to prepare this study.

The history of hospitals in Danzig goes back to the arrival of the Teutonic Knights in 1308. The earliest institution, according to historical sources, was the Hospital of the Holy Spirit, built in the years 1310-1311. It was run by the Hospitalet Order until 1382, and was intended for the sick, elderly and disabled people, orphans and needy pilgrim, and the poor.

Later centuries saw the further development of hospital services in Danzig. In the $19^{\text {th }}$ century, the city's increasing population, the development of the sciences, and rapid advances in medicine subsequently led to the establishment of three more hospitals in Gdańsk: The Hospital for Obstetrics and Gynaecological Disease (1819), the Holy Virgin Hospital (1852), and the Evangelical Hospital of Deaconess Sisters (1857), in addition to the old Municipal Hospital.

In 1911, new modern buildings of Municipal Hospital in Danzig were finished. On the basis of the Municipal Hospital, the Academy of Practical Medicine was established in 1935. It was known under the name Staatliche Akademie für Praktische Medizin in the Free City of Danzig. Five years later (in 1940) the Academy was developed and changed to the Medical Academy of Danzig (Medizinische Akademie Danzig - MAD).

The beginning of medical teaching at the middle level in Danzig (Gdańsk) dates back to the $16^{\text {th }}$ century. It had its origins in the Chair of Anatomy and Medicine at Danzig
Academic Gymnasium (GA; Sive Illustre), an establishment which lasted for 239 years, from 1584 to 1812 .

The history of surgery in Danzig has its roots in the centuries-old tradition of the medical practice of surgeons who were associated in the Surgeons Guild, teaching, as well medical and scientific research. The Surgeons Guild existed in Danzig from 1454 to 1820 . Over the centuries manual intervention was also in the hands of academically uneducated persons such as bath house attendants, barbers, and wandering surgeons.

Until the end of 1946 there was no separate urology department in Danzig. Urological surgery was in the hands of surgeons. Interventions and operations on genitourinary organs were carried out, more or less, in all surgical departments.

The end of World War II created a new political situation in Europe. Danzig (now Gdańsk) and Pomerania became part of Poland. In 1945, on the basis of the former MAD, the Polish Government established the Polish Academy of Physicians, later renamed the Medical Academy in Gdańsk (Gdańska Akademia Medyczna - GAM). In 2009, GAM was again renamed, as the Medical University of Gdańsk (Gdański Uniwersytet Medyczny).

The political changes after World War II accelerated the process of the separation of urology from surgery. In May 1947, a 30-bed Urological Ward was opened in Gdańsk, in Dębinki Street, forming part of the First Surgical Clinic of the Academy of Physicians (headed by Prof. Kornel Michejda, 1887-1960, later by Prof. Stanisław Nowicki, 1893-1972, and lastly by Prof. Zdzisław Kieturakis, 1904-1971). The first head doctor of the new urological ward was Dr. Tadeusz Lörenz (1906-1986), a urologist from Lvov (Lemberg). After the departure of Professor Lorenz to Wrocław (Breslau) in 1958, Dr. Jan Renkielski was acting as Head of the Urological Ward until 1971. In 1971 the ward was transformed to the separate Department of Urology. Docent ("lecturer"), and later Professor, Kazimierz Adamkiewicz from Zabrze (Hindenburg) became its Head. Professor Adamkiewicz organized and equipped the Department, leading it quickly to the level of modern departments in the areas of research, teaching, and therapy. During Professor Adamkiewicz's illness, and after his retirement in 1988, Docent Kazimierz Krajka, Later Professor) headed the urological department until his retirement in 2012. Since 1 October 2012, Associate Professor (Docent) Marcin Matuszewski (*1965) has been the head of the Department of Urology in Gdańsk.

K e y w o r d s: history of medicine - history of urology Gdańsk - Danzig.

\section{Introduction}

Gdańsk (Danzig) was an island of West-European culture. Originally belonging to Poland, it was inhabited by a Polish-Kashubian population. Later on, it became home 
to many immigrants from Germany, the Netherlands and other European countries.

The history of Gdańsk, like the history of many cities, is filled with ups and downs. But, unlike many other cities around the world, Gdańsk's history has a certain lateral motion, as it was tugged back and forth between the Poles, the Prussians, independence, Soviet influence, and even the Napoleonic armies. Through it all the drive for wealth and self determination were always present, and its storied past made it a likely home for its most recent historical surge: Solidarity.

The beginning of medical activity in Gdańsk is connected with the arrival of the Teutonic Knights in 1308. During this time the first barber surgeons started to practise, for example, Gerhardus Barbirason. There is a single mention of the arrival in 1354 of Johannes Medicus. Among later registrations (in 1391) one can find an Arnd Stensnyder. In the following period of time the number of barber surgeons increased. Many of them settled in Danzig, and some of them were very proficient operators.

The beginnings of the Gdańsk Hospitals and surgery practice can be traced to the $15^{\text {th }}$ century, and the buildings where smallpox was treated were called houses of smallpox, or lazarettos. The tradition of medical education in Gdańsk goes back many centuries. It had its origins in the Chair of Anatomy and Medicine at Danzig Academic Gymnasium, an establishment which lasted for about 230 years.

The history of surgery in this city has its roots in the centuries-old tradition of the medical practice of surgeons who were associated in the Surgeons Guild, teaching, as well medical and scientific research. These developments were particularly vibrant in the Gymnasium Academicum (GA, Athenaeum Gedanese). This institution established the Department of Science and Medicine (physics et medicine), which was managed and supervised by eminent scholars.

In the $19^{\text {th }}$ century hospitals came into being in Danzig: the old municipal hospital, the Hospital for Obstetrics and Gynaecological Diseases (1819), St. Mary's Hospital (1852), and the Evangelical Hospital of the Deaconess Sisters (1857). In 1911, new modern buildings of the Municipal Hospital in Danzig were finished (Fig. 1).

On the basis of the Municipal Hospital, the Academy of Practical Medicine was established in 1935. It was

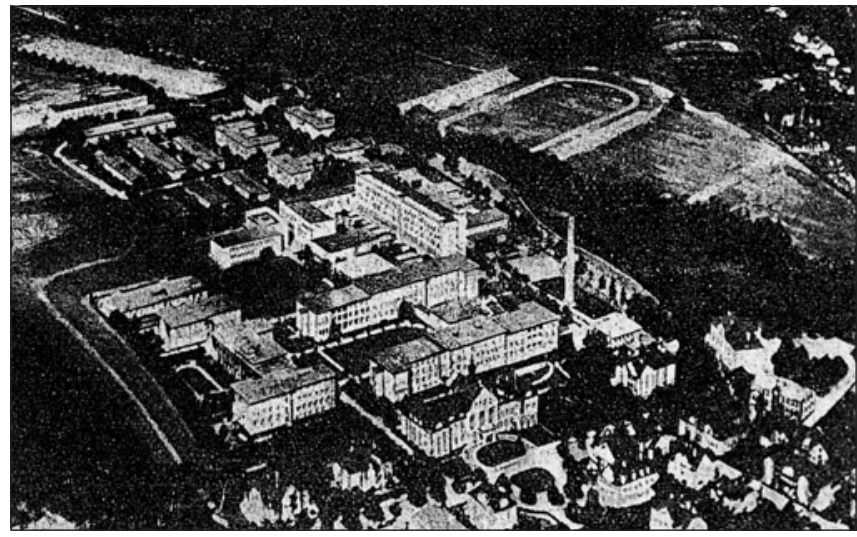

Fig. 1. Municipal Hospital in Danzig (about 1930) known under the name Staatliche Akademie für Praktische Medizin in the Free City of Danzig, later developing into the Medizinische Akademie Danzig. The latter may have been active only for a short time (1940-1945), but it was the first fully academic school of medicine in Danzig.

Between 1454 and 1945 there was a steady increase in the level of medical knowledge, putting Danzig on an equal footing with the best examples of European medicine and surgery.

The Polish medical academic institution (Gdańska Akademia Medyczna) was founded in 1945. In 2009 the establishment was renamed the Medical University of Gdańsk (Gdański Uniwersytet Medyczny).

With regard to urology as a speciality, it has now existed in Gdańsk for almost seven decades, since 1947. The chief of the first urological ward was Dr. Tadeusz Lorenz (later Professor). The present academic urology clinic was founded over forty years ago, in 1971. Its first head physician was Docent ("lecturer"), and later Professor, Kazimierz Adamkiewicz $[1,2,3,4,5]$.

\section{Danzig's Gymnasium - “The Physicians' School” (1555-1820)}

The first gymnasium ("high school") of an academic nature was founded in Danzig in 1555. It was located in an old monastic building once occupied by Franciscan monks, and was also known as the Franziskaner or "Graue Kloster", which was evacuated after the Reformation (Fig. 2).

The school operated in its original manner for the next two and a half centuries, until 1812. The syllabus of the last two years included natural philosophy and medicine, and, depending on their inclination, students in the higher classes could devote more time to their preferred subject. In other words, they could choose medicine as their main field of study. The original objective of the Gymnasium at the time of its foundation was to promote Protestantism and theologico-philosophical knowledge.

There were also plans to transform it into an academy or a university, and to this end medical studies were

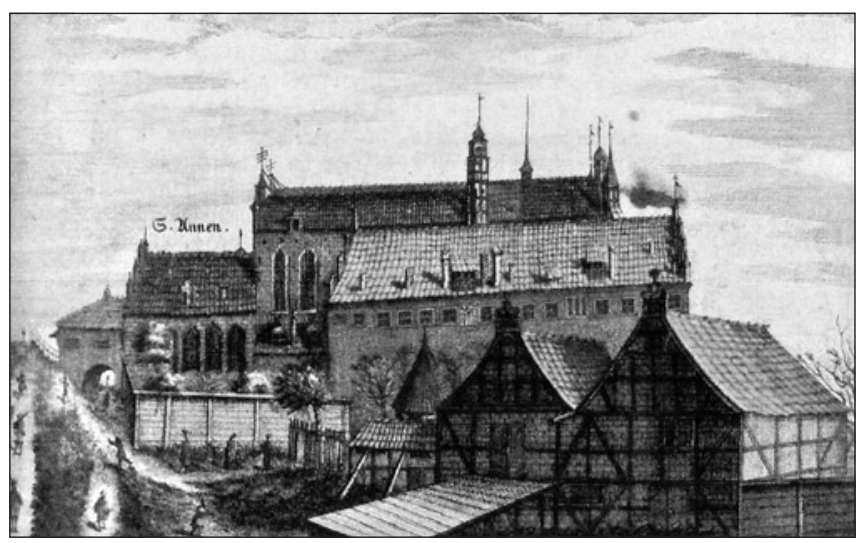

Fig. 2. Franziskaner Kloster. From 1555 Danzig's Academical Gymnasium 
introduced, such as anatomy and materia medica, as well as natural history, botany, "physices", and astronomy. But the Gymnasium never achieved its planned glory. Its name was changed to "Athenaeum", but they lacked the courage to call it an "Academia".

Nevertheless, its standard of teaching was very high for those days. In fact, so high that many West European universities admitted its graduates at third-year level for medical studies. It can be seen that the Gymnasium had a higher standard than the secondary school that its name implied, and provided education corresponding to the first two years at a university. After the closing of the Gymnasium at the beginning of the $19^{\text {th }}$ century it was not until the $20^{\text {th }}$ century that another academic school was established $[3,6,7]$.

\section{Danzig's Anatomical School (1584-1812)}

The foundation of the Gymnasium Academicum contributed to the development of medical knowledge, and especially knowledge about human anatomy - thanks to the official autopsies performed there, and the manuals of Prof. Johann Adam Kulmus (Fig. 3). The time of the

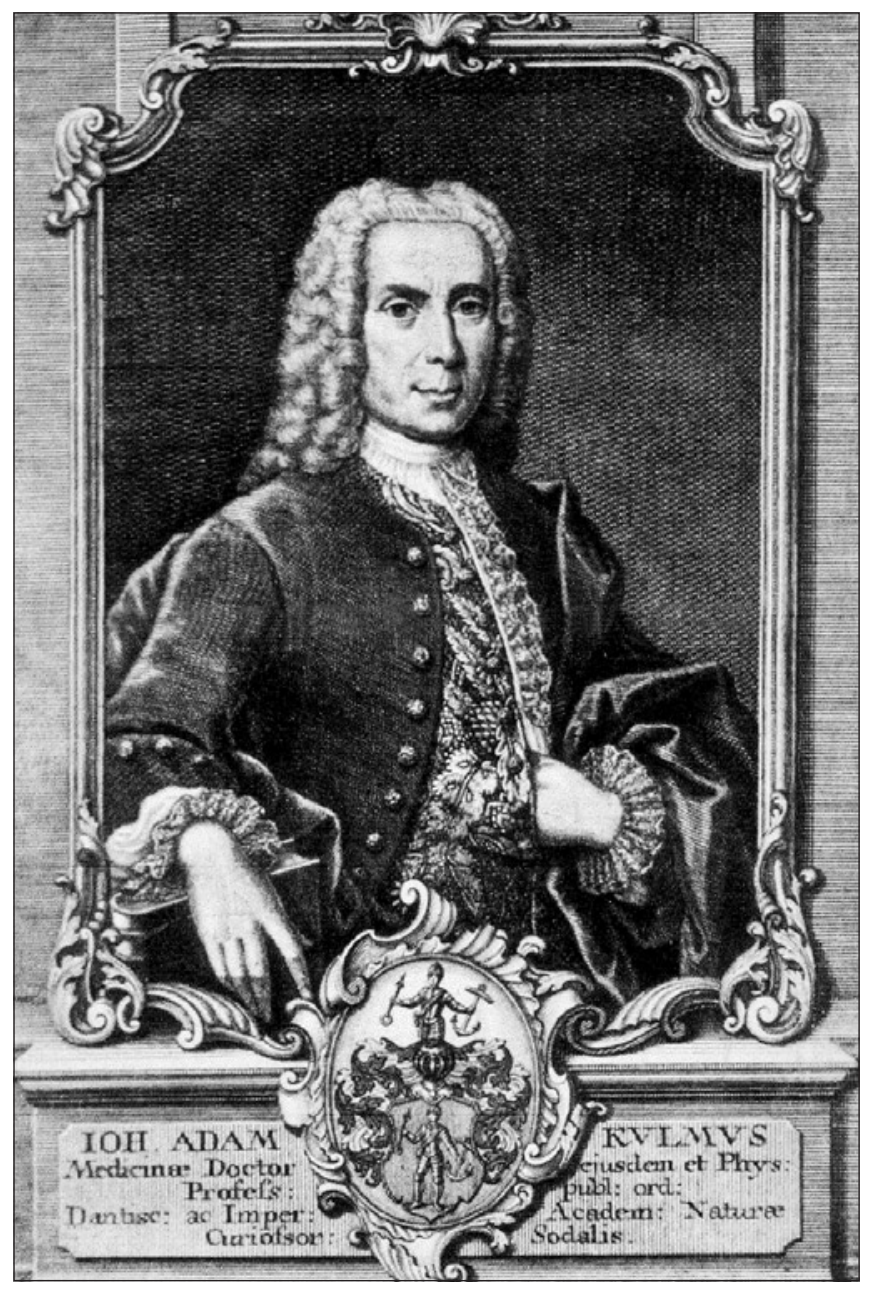

Fig. 3. Johann Adam Kulmus (1689-1745) foundation of the Academic Gymnasium in Danzig was closely connected with the time of decline of the Jagiellonian Academy in Cracow and the Academy in Zamość, in Poland.

It was a time of reaction after the Reformation, the twilight of the Polish Golden Age, and the decline of the sciences during the reign of Sigismund III Vasa (1566-1632), the King of Poland. For the next hundred years and longer, therefore, the development of science stagnated in the entire Polish Kingdom.

At the same time, in the western world, this was a period of the most intense flourishing of anatomy, largely triggered by the work of Andreas Vesalius (1514-1565). In this situation a school of anatomy, free from superstition and developing right next door, in Danzig, was a heaven-sent gift to Polish science, and exerted a major influence on the mentality of Polish physicians.

Independently of regular lectures in anatomy, the school took care to organise demonstrations of dissection, always an opportunity to present "whole anatomy" to the audience. The first public dissection, on the body of a badly malformed newborn infant, was carried out by Joachimus Oelhafius (1570-1630) in 1613, as may be seen from his description of the baby's organs. The performance of regular dissections in Danzig as early as 1613 was of great significance, bearing in mind that at that time dissections in Germany were a rarity. The first recorded dissection in Warsaw was not until 1736, and almost ended in tragedy because a mob gathered and wanted to stone the master of ceremonies Doctor Löhlöffel, great-grandfather of the renowned historian Joachim Lelewel (1786-1861). Numerous young Poles passed through and even studied at Danzig, and this had a positive influence on many Polish doctors.

The dissection carried out by Johannes Glosemayer (1696-1711) in 1696 was characterised by an air of ceremonial pompousness, like the dissections in Western Europe. The introduction of this discursive style of teaching was due to Joachimus Olhafius, who led many discussions on selected subjects, and with selected participants acting as his opponents. In the course of 20-old years he thus covered virtually the whole range of human anatomy. His partners in the discussions also included Poles such as Alexander Myslovius, Samuel Macovius, and others.

This ceremony was increasingly evident in the dissections performed in the $18^{\text {th }}$ century by Johann Adam Kulmus (1689-1745). A properly fitted out dissection amphitheatre was already in existence in Danzig at that time, where discussions were important, apart from the demonstrations, during which members of the audience could be invited to help with the dissections (Fig. 4). His famous book "Tabulae Anatomicae" was published in 1722 (Fig. 5). The book was equipped with several copper plates for illustrations, which included Plates XXV and XXVI, genitourinary illustrations (Fig. 6). This book was written by the medical doctor Kulmus, specially to educate the apprentices and fellows of surgeons in the German language. The formerly used 


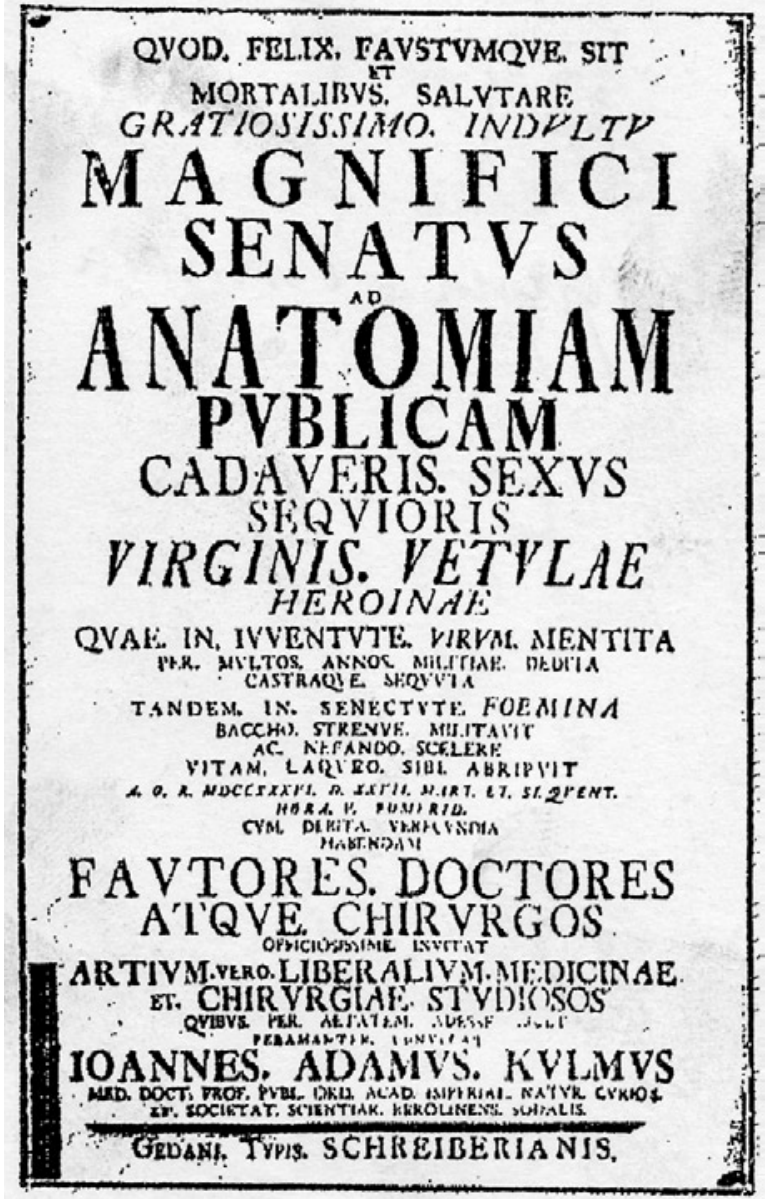

Fig. 4. Kulmus's notification on the public autopsy (1735)

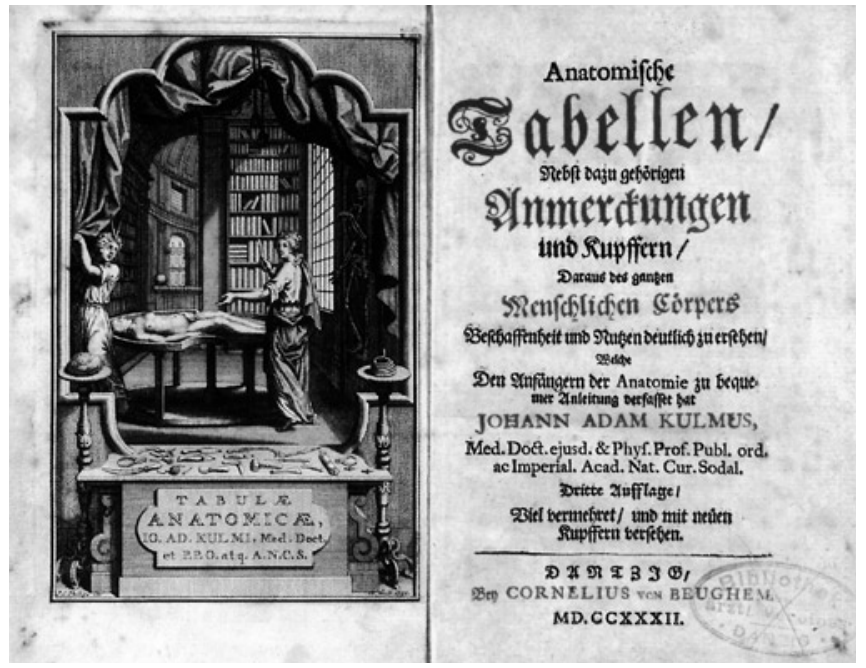

Fig. 5. Title page of "Tabulae Anatomicae" (1732)

oversized anatomical atlases which were published in Latin had been without any use and were much too expensive for educational purposes for pupils, guild surgeons and young practitioners. The work became very popular, was released in 23 different editions, and was translated into seven languages, including Japanese.

The book was the first Western scientific monograph of anatomy to be translated entirely from Dutch edition into

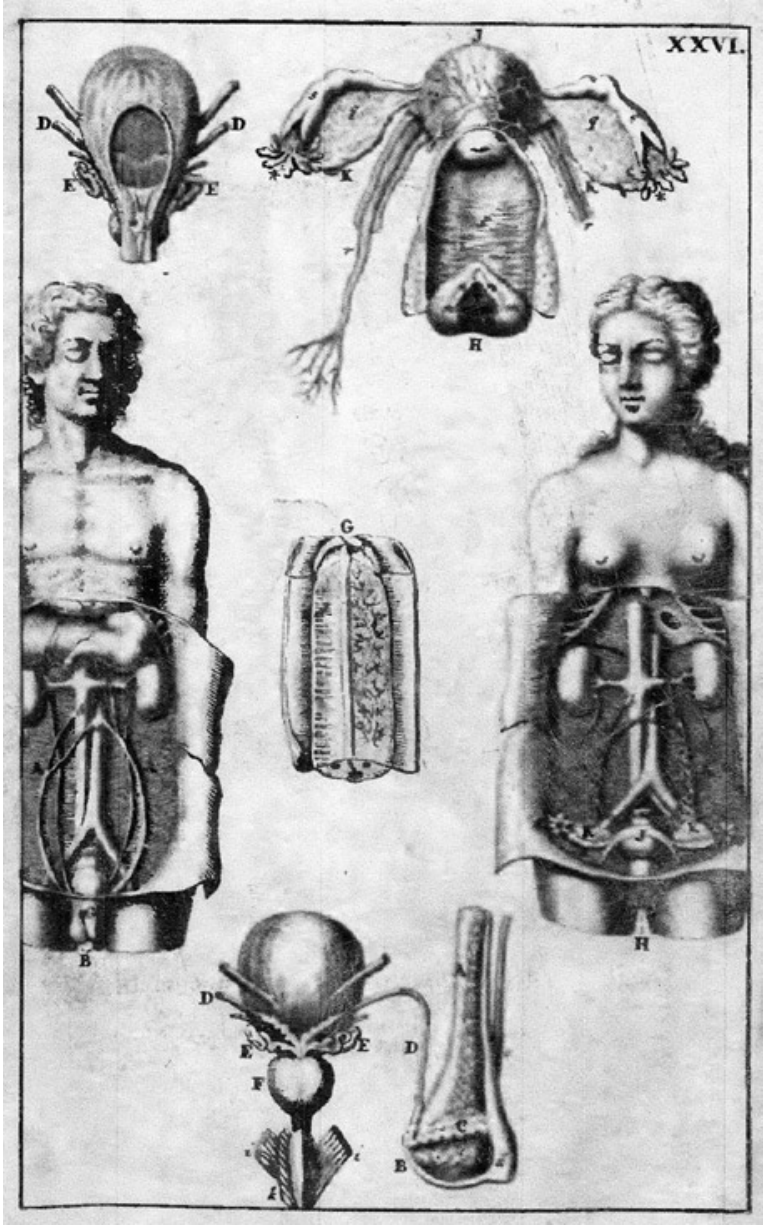

Fig. 6. Genitourinary illustration from Kulmus’ Tabellen (1732)

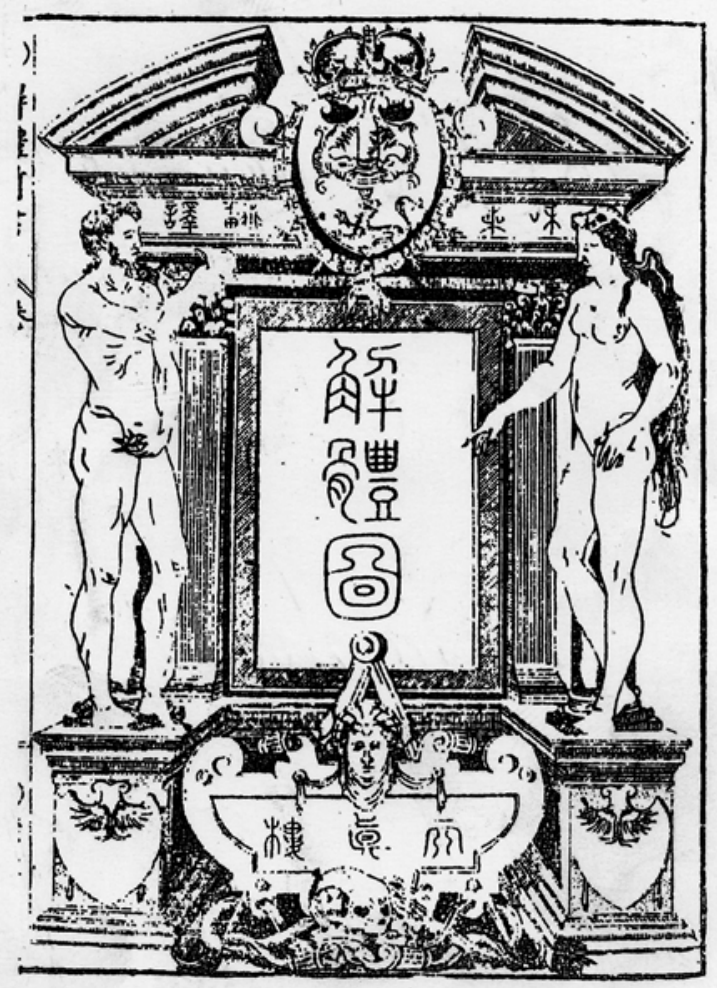

Fig. 7. Title page of "Kaitai Shinsho" (1774) 
Japanese, and was published in 1774. This book, entitled "New Book on Anatomy", was supplied with numerous wooden engravings. The book achieved numerous editions and renewals. In 1826, Otsuki Genataku (1757-1827) issued a "Chotei Kaitai shinsho", it was revised and supplemented version of the translation work Kulmus. It was also a large step in the development of European medicine in Japan. It also launched the Western-stile study of medicine in Japan (Fig. 7) [5, 7, 8, 9].

\section{Wandering surgeons}

Surgical conditions, cataracts, hernias, and bladder stones had always plagued humanity and, depending on the epoch, were treated by specially trained practitioners. Surgery was at first in the hands of physicians, and developed best where there were active schools of medicine. Then, after monks and the clergy had been forbidden to engage in surgery: "The Church abhorred the shedding of blood" (Lateran Council on Tours of 1163: "Ecclesia abhorret a sanguine"), the profession began to pass into the hands of the uneducated, such as bath house attendants, barbers, and even executioners. Some of them became itinerant surgeons by acquiring some surgical knowledge.

They tended to specialise in just one type of intervention, e.g. in lithotomy, cataracts, hernias, pulling teeth, blood-letting and the like. They were characterised by a particular activity, made use of occasions for large congregations of people such as markets or church fairs to practise their trade, and often noisily advertised their services. Later on, some of them became well educated and skilled specialists in their profession. The wandering lithotomists ranked even lower than barber-surgeons, but some of them were very proficient operators. Their fame was known in Europe or their own country. One of them was the famous French wandering lithotomist (Frère) Jacques de Beaulieu (1651-1714). Another one was the German itinerant surgeon Johann Andreas Eisenbarth (1663-1727). In 1723, Eisenbarth visited many Prussian cities to conduct his operations: Königsberg, Elbig and Prussian Holland, also Marienburg and Danzig, in 1724 (now: Kaliningrad, Elbląg, Warmia/Mazury, Malbork and Gdańsk) [3, 10].

\section{Danzig's guild of surgeons (1454-1820) and settled barber-surgeons}

As time passed, surgical training and activity in Central Europe became shaped by the rules governing trade organisations. Such organisations had arisen as an expression of the craftsmen's desire for self-determination and protection of their interests. In time they became guilds, and hence surgery from that period is known as guild surgery, and its practitioners as Medici ciroici. For a few centuries surgery and manual treatment stopped being practised by physicians and became the province of trained guild members or barber-surgeons (barbitonsores) settled in towns.

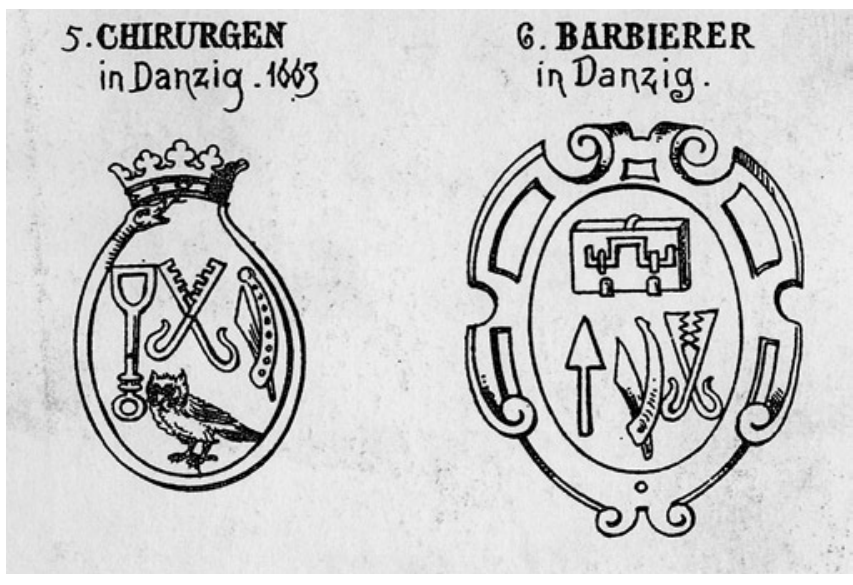

Fig. 8. Coats of arms of surgeons and barbers

During the years 1454 to 1820 there was a Guild of Surgeons in Danzig, in the master workshops of which apprentices learned their future trade (Fig. 8). On 27 March 1454 the Council of the Old City of Danzig confirmed the statute of the Danzig guild of surgeons. The statute contained a whole set of regulations, entitlements and guild customs. The desire to maintain the elite character of the guild went hand in hand with concern for the highest possible quality of its services. It took three years to become a master surgeon, and during the guild's golden age future practitioners of the art of surgery supplemented their knowledge at the Danzig Academic Gymnasium. There they would study human anatomy, the basics of physiology, and questions connected with the prevailing ideas of health and disease.

For four hundred years, until 1820, manual treatment with the use of manipulation (surgery) was not a field of activity for physicians. It was a time of separation between surgery and medicine, and it was not until the $19^{\text {th }}$ century that surgery became part of academic medical schooling at university level $[2,5,7,10]$.

\section{Surgery in the Danzig Municipal Hospital (1896-1935)}

The first real municipal hospital in Danzig stems back to the $17^{\text {th }}$ century. It was comprised of 15 rooms for patients and one operation room. In the $19^{\text {th }}$ century, the number of hospitalised patients was 600-700 per year. At that time numerous skilled surgeons worked in Danzig.

From 1907 to 1911 a new, modern 700-bed municipal hospital complex at Danzig-Langfuhr, Delbrückallee (now Gdańsk-Wrzeszcz, Dębinki) was erected, and was officially opened in April 1911. The first Head of the Surgery Department was Professor Arthur Barth (1858-1926), from Marburg, Germany (Fig. 9).

Arthur Barth was born on 20 February 1858 in Untergreißlau, Saxony-Anhalt (Germany). His father was a long-serving general practitioner in Naumburg. After selling his practice he took up farming on his family estate. Arthur 
received his primary education at home. In 1877, he graduated at the elite National School in Pforta.

He studied medicine in Jena, Marburg, and Berlin, and graduated in 1882 in Jena. That same year he received his doctorate at Jena University, for his thesis: "On the relationship between the diameter of pelvic narrowing and the pelvic inlet". He completed a 1-year course in obstetrics at the Institute of Obstetrics in Dresden, and in Vienna.

Dr. Barth gained his surgical training in several departments and clinics across Germany, always under the guidance of eminent surgeons (Prof. Ernst Küster, 1839-1930 in Berlin, Dr. Georg Wilhelm Braun, 1836-1895 in Danzig and again over a long time by Professor Küster). When Professor Küster was appointed Director of the Surgical Clinic at the University of Marburg, Doctor Barth soon followed his former chief, and on 1 November 1890 started work as principal assistant in the Surgical Clinic at Marburg, becoming Deputy Head of Department in 1891. In 1892 he qualified as Assistant Lecturer with the habilitation thesis: "On histological changes occurring during the treatment of renal lesions, and behaviour of the renal parenchyma". His experimental-clinical dissertation, based on his activities at the University of Marburg, concerned the assessment of treatments for kidney lesions (1892). In 1896 he was appointed Associate Professor.

In 1896 Professor Barth took over from Dr. Wilhelm Baum as Director of the "old" Gdańsk Municipal Hospital in Zaspa (Sandgrube). Barth played a significant part in the planning and execution of the modern Municipal Hospital complex in Danzig. Among the distinguished personages involved in the establishment and development of the modern Municipal Hospital in Danzig was its first Director, the surgeon, academic and author, Prof. Arthur Barth. The facility was completed in 1911. Barth became Director of

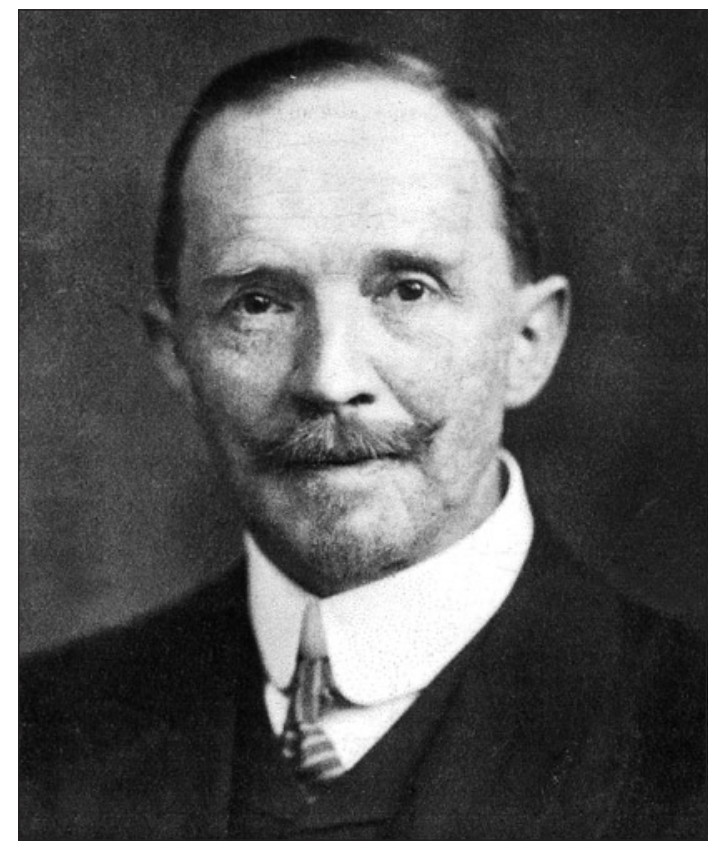

Fig. 9. Professor Arthur Barth (1858-1927) the Surgical Clinic in the newly-built municipal hospital. He headed a 360-bed department of surgery in Danzig until 1924.

He was an outstanding specialist in osteoarticular surgery and maxillary surgery, as well as of the abdominal cavity and urology, but his primary speciality was renal surgery. Barth's Marburg days, in the closing decade of the $19^{\text {th }}$ century, produced some of his most highly appreciated research studies of global significance, among other things about the artificial production of bone tissue grafts in cases of joint degeneration and bone transplantation. His academic works touch upon many areas of surgery. He is well known for his bone and articular experimental works. These publications are cited in the current world literature.

Like many surgeons at a time when new departments were moving away from surgical medicine, Barth carried out urological operations and published more than 30 outstanding works in urology. Of special significance were his publications on subjects as diverse as the treatment of renal lesions (doctoral thesis), renal section, purulent kidney disease, horseshoe kidneys, hypertrophy and atrophy of the prostate gland, renal tuberculosis, renal abscesses and urolithiasis, as well as his many publications relating to other systems and disorders. These include inflammation of the pancreas, gastric and duodenal ulcers, cancer of the larynx, inflammation of the paranasal sinuses, and neoplasms of the oral cavity.

His activities as a surgeon were valued not just in Danzig; his fame extended beyond West Prussia, as far as Pomerania. As a long-serving, versatile professor of surgery he made a significant contribution to the development of modern surgery.

He took part in World War I on Polish territory and in France as Surgeon-General, and as a consultant and surgeon to the $17^{\text {th }}$ Army Corps. He received the Iron Cross $2^{\text {nd }}$ Class and $1^{\text {st }}$ Class, and in 1916 he was awarded the noble title of "Secret Medical Adviser" (Geheimen Medizinal-Rath).

In 1924 Barth fell victim to influenza, which was complicated by inflammation of the heart muscle. On 1 November 1924, after spending altogether 30 years of his life at Danzig, at his own request, he was retired and went to live in Schwerin. There, he was active in the local Medical Association and devoted his time to writing, including an autobiography. He died on 7 May 1927 in Schwerin and was cremated in Lübeck.

From the very beginning of its existence the Municipal Hospital was constantly in a process of extension and rebuilding. After a hospital base was set up, new departments and clinics were constantly being opened.

In 1924 Prof. Heinrich Klose (1879-1968), a disciple of Prof. Ludwig Rehn (1849-1930), was appointed director of the Surgery Clinic, and he ran it until 1945 [11, 12].

\section{The Free City of Danzig (1920-1939)}

The Free City of Danzig (German: Freie Stadt Danzig; Polish: Wolne Miasto Gdańsk) was a semi-autonomous city-state that existed between 1920 and 1939, consisting 
of the Baltic Sea harbour of Danzig (today Gdańsk) and surrounding areas. It was created on 15 November 1920 in accordance with the terms of Article 100 (Section XI of Part III) of the 1919 Treaty of Versailles.

The Free City included the city of Danzig and over two hundred nearby towns, villages and settlements. As the Treaty stated, the region was to remain separated from the nation of Germany and from the newly resurrected nation of Poland, but it was not an independent state; the Free City was under League of Nations protection and put into a binding customs union with Poland. Poland was also given full rights to develop and maintain transportation, communication, and port facilities in the city. The Free City was created in order to give Poland access to a good-sized seaport while respecting the fact that the city's population was roughly 93\% German. The Polish minority in the city continued to be oppressed and Germanized by the local German authorities.

In 1933 the City's government was taken over by the local Nazi Party, and democratic opposition was suppressed. Due to anti-Semitic persecution and oppression most Jews fled. After the German invasion of Poland in 1939 the Free City was abolished and incorporated into the newly formed Reichsgau of Danzig-West Prussia. Anti-Polish measures followed [13].

\section{From Municipal Hospital to the Medical Academy of Danzig}

In 1924 Prof. Heinrich Klose (1879-1968) from Frankfurt am Main, Germany, took the Surgical Clinic over from Arthur Barth as the head of a 400-bed institution (Fig. 10).

Heinrich Klose was born on 31 August 1879 in Ibbenbüren, Westphalia (Germany), where his father was a railway official. Heinrich attended the Protestant school (Evangelisches Gymnasium) in Guetersloh, passing his school-leaving examination in 1898 and going on to study for three years in the Faculty of Medicine in Goettingen. He finally finished his studies in Strasbourg in 1903. There too he obtained his doctorate, for the thesis "On scarlet fever in children, with particular reference to fever".

Klose received his complete training of surgery in Frankfurt am Main, first as a junior assistant and later as an assistant professor and lecturer (Pivatdozent) under Prof. Ludwig Rehn (1848-1930). He then served as an assistant professor to Rehn's successor, Prof. Viktor Schmieden (1874-1945).

He took part in the World War I, serving as the head of a medical unit, in recognition of which he was decorated with the Iron Cross of Class I. He described his war surgical "Experiences of solitary gunshot wounds of the kidney", and in 1917 published it in Medizinische Zeitung (Medical Gazette).

In 1916 he obtained his habilitation in surgery in Frankfurt on the basis of his thesis "Chirurgie der Thymusdrüse" (Surgery of the Thymus Gland), a work carried out under Prof. Ludwig Rehn. He then embarked on a period of intensive scientific work, publishing, among others, a number of papers on urology.
Professor Klose headed Danzig's Surgical Clinic from 1924 until 1935. During the period between the wars this was the most advanced institution in Northern Province Prussia.

It was during this Danzig period that his most important book, known the world over, "Surgery of Basedow's Disease", was published. His reputation went far beyond Danzig and the frontier of Germany. In 1938 he operated, among others, in Moscow on Mikhail Kalinin, the Chairman of the Presidium of the supreme Council if the USSR, after whom the modern city of Kaliningrad was named. Klose played a significant part in the foundation and further development of the Danzig School of Medicine, strongly promoting the need for such an institution in the local Danzig press as early as in the 1920s. It was on the basis of the Municipal Hospital that the Academy of Practical Medicine was formed in 1935. Among the distinguished personalities involved in the creation and further development of the Danzig School of Medicine was Professor Heinrich Klose, the first director of its Surgical Clinic. He served as Director of the Surgical Department between 1935 and 1945. Professor Klose was a general surgeon with wide skills, and was an excellent operator and teacher. He took particular interest in abdominal, breast and thyroid gland operations. During the last decade of his activity in Danzig, in addition to the routine duties of the Head of the Clinic, Klose paid particular attention to the teaching and training of medical students and problems of "Genitourinary war injuries". On 31 August 1939, on the occasion of his $60^{\text {th }}$ birthday, the Senate of the Free City of Danzig awarded him "Kreuz von Danzig" (the Cross of Danzig), the prestigious Prize of the City.

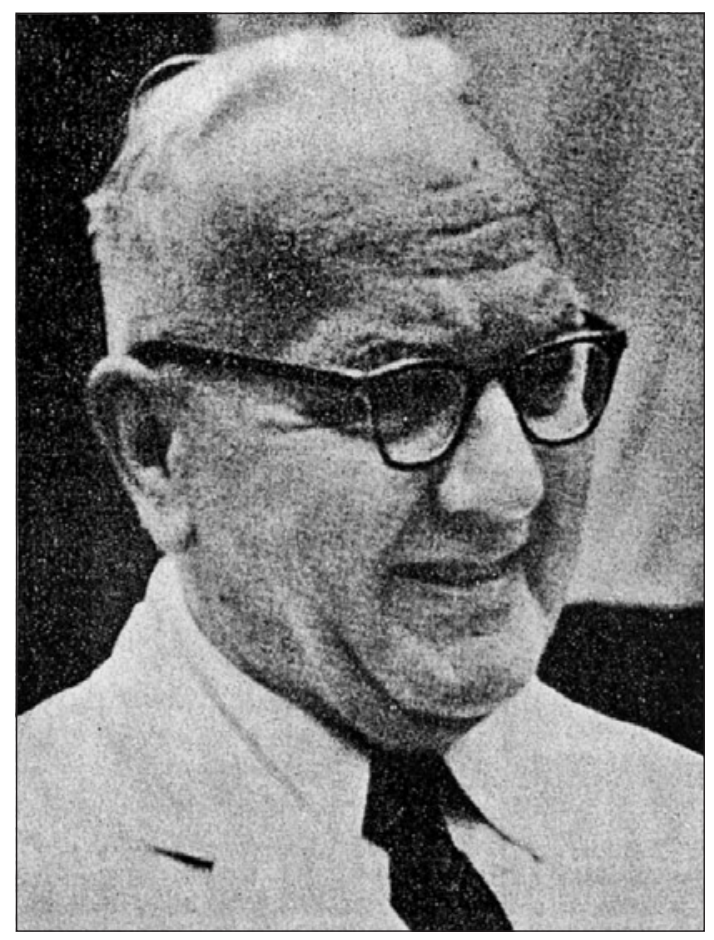

Fig. 10. Professor Heinrich Klose (1879-1968) 
On 26 March 1945 Professor Klose was arrested, interrogated repeatedly by the NKVD, the Soviet Secret Police, and imprisoned. Following his release from the Soviet war prison, Klose departed for East Germany.

On his arrival in East Berlin he worked as Head of the Surgical Clinics. Between 1948 and 1960 he was the senior surgical registrar of the Municipal Hospital in Berlin-Friedrichshein, where he was also the Director of the hospital complex, which he rebuilt from ruins and subsequently modernized and extended, with the addition of an extensive Department of Gynaecology. As he once did in Danzig, now in Berlin he devoted much of his time to the teaching of students and young doctors. He was a particularly prolific author during this period. Professor Klose served for many years on Berlin City Council, allowing him to play an important part in rebuilding the city's medical services. He was among the first to be awarded the honorary title "Verdienter Arzt des Volkes" or People's Distiguished Physician. In 1951 he became a member of the Academy of Sciences, and in 1953 received the Goethe Prize of the City of Berlin. Professor Klose died on 19 November 1968 in Bad Eilsen at the age of 89 . He was interred in the Evangelical Cemetery in Minden (Westphalia, Germany) [2, 5, 10, 14, 15, 16, 17$]$.

\section{Academic teaching and medicine in Danzig (1935-1945)}

On 13 April 1935 the Senate of the Free City of Danzig held a ceremony in Artus Court to establish a School of Practical Medicine with the official name of Staatliche Akademie für Praktische Medizin zu Danzig. The ceremony was preceded by a resolution of the City's Senate on 4 December 1934.

A special issue of "Die Medizinische Welt" ("Medical World") appeared in connection with the ceremonial inauguration of the School of Practical Medicine (Fig. 11). The same issue also contained the text of a speech by Dr. Norbert Appaly, Chairman of the Gdańsk Medical Association, and an article entitled "A look back at the history of Danzig medicine" by Dr. Paul Ziegenhagen, then a Professor of the History of Medicine at the new academy.

The School of Practical Medicine was at first staffed by 12 professors, whose names and portraits appear in the above-mentioned issue of Die Medizinische Welt in 1935. It is worth noting in this context that its organisation was based on the example of a similar seat of learning in Düsseldorf. Most of the professors at the school of medicine before World War II, and also in the years 1939-1945, were German nationalists, members of the Nationalsozialistische Deutsche Arbeiterpartei or the NSDAP (National Socialist German Workers Party), and enjoyed the confidence of the authorities of the Third Reich.

Teaching medicine in the newly opened college involved clinical courses. The Danzig School of Practical Medicine was intended for students who had already gone through

\section{DIETIEDIZINISCHE \\ SCHRIFTLEITUNG \\ PROFESSOR DR \\ DR. CL. E. BENDA ШELT

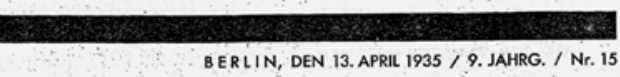 \\ BERLIN, DEN 13. APRIL 1935 / 9. JAHRG. / Nr. 15}

ZUR EROFFNUNG DER STAATLICHEN AKADEMIE

FUR PRAKTISCHE MEDIZIN ZU DANZIG

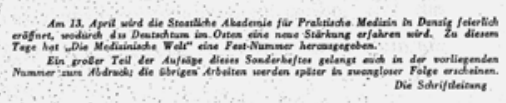

Einsatz der praktischen Ärzte und Medizinstudierenden

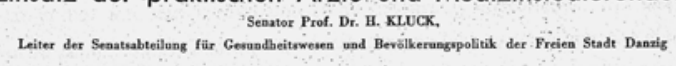

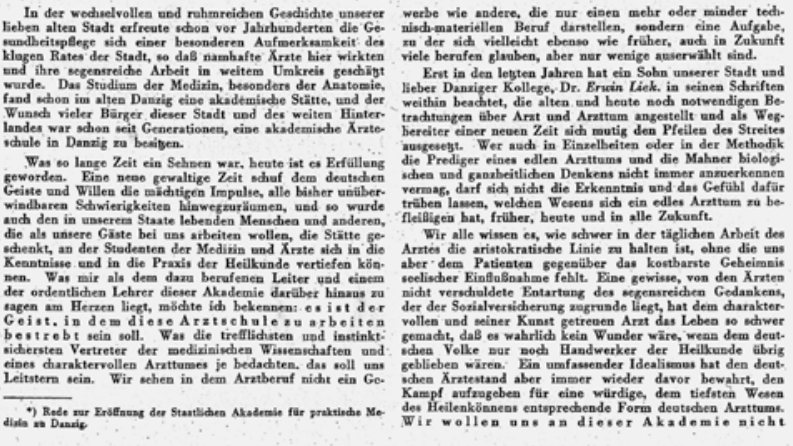

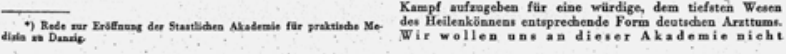

Fig. 11. Die Medizinische Welt (1935)

preclinical studies at one of the German universities. It provided particularly favourable conditions for gaining practical experience in clinics set up on the basis of hospital departments of the Municipal Hospital (built in 1907-1911, Delbrückallee, and subsequently extended after 1921, near what is now Dębinki Street), the Hospital for Obstetrics and Gynaecological Diseases, Women's Clinic (until 1945 Provinzial Hebammen Lehranstalt Langfuhr, Frauenklinik), the Diaconal Sisters Hospital (Diakonissenshaus), and the Orthopaedic Hospital. All in all, there were at that time about 1500 hospital beds in Danzig, which were available for didactic purposes - for the practical training of medical students. A student wanting to take the German national medical examination had to have to his credit 6 semesters of clinical studies: the clinical studies in Danzig were counted as only two of these, and the remaining four had to be completed at a school of medicine in Germany. Up to 1939 the Danzig School of Practical Medicine was not entitled to hold medical diploma examinations $[3,11,15,16,17,18,19]$.

\section{The Medical Academy of Danzig (1940-1945)}

In 1940, following the introduction of pre-clinical courses, the name of the college was changed to Medizinische Akademie in Danzig (Medical Academy of Danzig - MAD), now offering full 5-year medical studies. Intensive activity aimed at creating an academy offering a complete course of study in Danzig began in the School of Medicine in 
1940, during World War II and after Danzig had de facto become part of the Third Reich. German docents and professors in non-clinical specialisations were brought over from various German universities, placed in charge of corresponding departments, and given the task of organising individual institutes. And in this way the Staatliche Akademie für Praktische Medizin zu Danzig, which had already been operating for the past five years, was transformed in 1940 into a full academic school of medicine and renamed Medizinische Akademie Danzig or MAD.

Students were now also accepted for the first year of studies, and the academic year was restructured into three semesters. The Ministry of Science and National Education in Berlin raised the position of Director of MAD to the status of Rector. Dr. Erich Grossmann was appointed Rector and was made a Professor. The Academy's secretariat, the faculty offices, the rector's office, and all administrative organs were located at $14 \mathrm{~b}$ Wall Street (now Wałowa Street), in an extended complex also housing the Institut für Erbbiologie und Rassenhygiene (Institute for Heredobiology and Eugenics) - Figure 12.

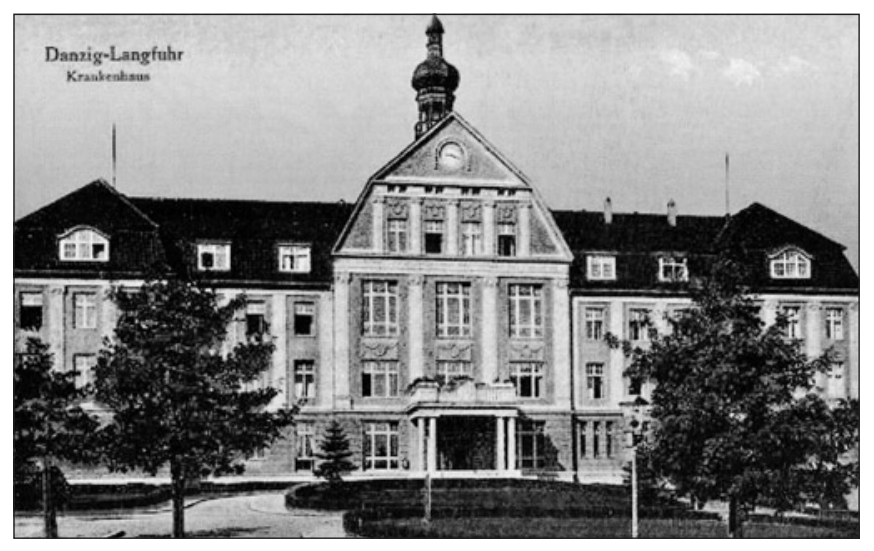

Fig. 12. Administration of the Medical Academy

During the nearly five years of the existence of MAD a number of doctoral supervisions and postgraduate studies were completed, as a result of which a considerable number of local Danzig doctors working in the Academy, and doctors from other cities, were granted the title of Docent ("lecturer") or Assistant Professor.

The above-described German medical establishment functioned in Danzig for close to ten years, and during the last five years of this period it had a complete Faculty of Medicine and held academic entitlements obligatory in the German higher education system. It was one of the two faculties of medicine in the German Reich that were not part of a university - the other was a school of medicine in Düsseldorf formed considerably earlier, an educational institution separate from the university.

The educational activity of MAD ended in 1944-1945, when a considerable proportion of its staff and its students were transferred to diverse military units, and not only to positions in the Wehrmacht's (Military) Medical Service. This happened not only to the Students Company, but also to civilian students. In any event, the Students Company was disbanded around the middle of November 1944 and transferred to Gottingen.

During World War II two Danzig hospitals were appointed for the care of the wounded returning from the Eastern Front: the Surgical Clinic of the Medical Academy, and the Surgical Department of the Diaconal Sisters Hospital, and their directors, Professor Heinrich Klose (1879-1968) and Professor Georg Büttner (*1891) acted as surgical advisers to doctors of the Wehrmacht Medical Service.

During the war approximately 130 consultant surgeons, professors from important surgical institutions, were called up from the entire Reich, in order to provide advice, train staff and medical personnel, gain experience, and develop scientific solutions to newly arising problems in the care of the wounded. Another of their tasks was to develop unified procedures for treating wounds in particular organs and parts of the body, e.g. "experience and standards (guidelines) for the treatment of traumas sustained by genitourinary organs" $[1,3,15,16,20]$.

\section{The end of the World War II (1944-1945)}

An immense wave of refugees from the approaching front and the Soviet army advancing from the east passed through Danzig towards the end of the war, and soon a considerable proportion of the natives of Danzig too became refugees fleeing westwards by land and by sea. Some of the Academy's teaching staff was also evacuated from Danzig at this time, while others - mainly clinic doctors and professors - stayed behind and left the city only after the cessation of military operations.

On 31 January 1945 a considerable proportion of assistant professors from the Danzig Technical High School went to Gottenhafen (Gdynia) on board the MS Wilhelm Gustloff (Fig. 13), together with their families, also taking with them the polytechnic's archival collections, the library, and valuable scientific publications with the aim of carrying them

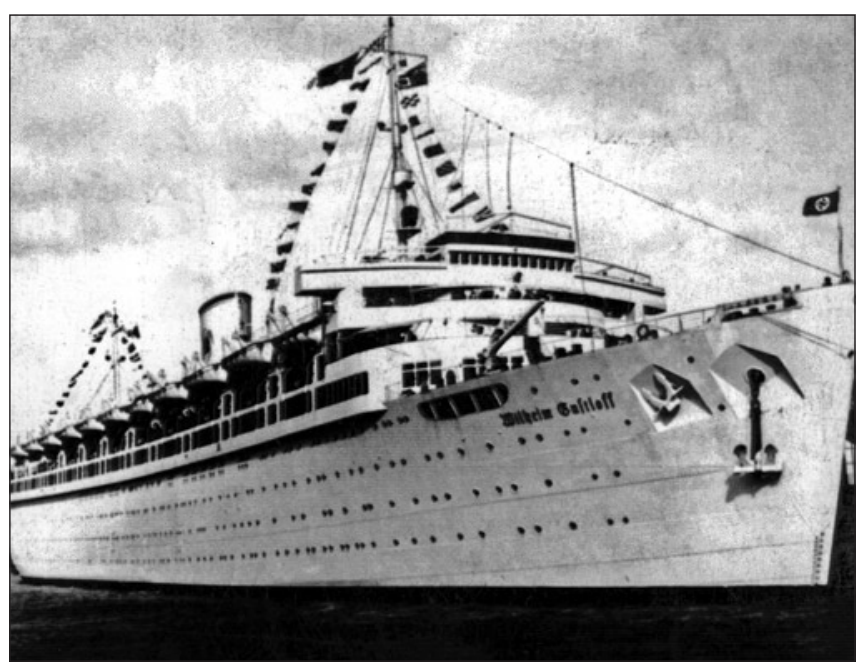

Fig. 13. MS Wilhelm Gustloff (1945) 
quickly to Kiel or at least to Swinemünde (Świnoujście). However, during the dark and stormy night of 1 February 1945 the ship was torpedoed by the Soviets and sank. Over 9400 people, including soldiers and some Nazis and Gestapo (secret police) members with families lost their lives. Only 1252 passengers were rescued. It was the greatest loss of life in a solitary maritime disaster in history. Lost too were the collections and probably also some of the staff from MAD.

During the city's conquest by the Soviet Army in the early months of 1945 many citizens fled. Thousands of people froze to death, mostly children and babies, in icy snowstorms and $-20^{\circ} \mathrm{C}$ weather, or were killed. After the war a number of remaining ethnic Germans were expelled. The city subsequently became part of Poland, as a consequence of the Potsdam Agreement, and Polish settlers were brought in to replace the German population $[3,15,16,21]$.

\section{The early post-war period}

The post-war destinies of the people working at MAD were many and various. Some found employment in educational institutions in the Federal German Republic, others in non-academic medical establishments. Some went to work in East Germany (Prof. Heinrich Klose). The Rector, Professor Erich Grossmann, fearing prosecution in Gdańsk as a former officer of the SS, committed suicide in a British prisoner of war camp near Hamburg. Rudolf Spanner, Professor of Anatomy at MAD and another member of the SS, successfully passed a "denazification" process in West Germany and worked as an assistant lecturer and later full professor in Cologne.

Regrettably, some of the Professors later suffered defamation of character, and here the case of Prof. Rudolf Spanner offers a prime example. Professor Spanner, an anatomist, was said to have been making soap from human fat - a fantasy propagated by a Polish writer, Zofia Nałkowska (1884-1954). Several pseudoscientific pronouncements and newspaper articles appeared on this subject, but there was never any proof of the allegations, and they should not be allowed to throw a shadow over the 10-year history of the Danzig school of medicine prior to 1945. The German MAD should also be remembered. Its activity was brief and in a stormy period of European history, but nevertheless it was the first fully academic school of medicine in the Free City of Danzig $[3,22,23,24,25]$.

\section{Urology in Danzig until 1947}

Up to the end of 1946 there were no independent urology wards in Danzig, and urological surgery was in the hands of surgeons, and also over the centuries in the hands of academically uneducated persons such as bath house attendants, barbers, and wandering surgeons.
Between the two world wars interventions and operations on genitourinary organs were carried out in all surgical departments. Professor Barth was engaged in urological surgery, especially urinary stone treatment and renal injures.

Professor Klose published some urological articles. He also devoted himself to urological surgery, especially kidney operations and endoscopy, and the treatment of war injures of the genitourinary organs. Klose and his Associates regularly gave lectures and ran courses for medical students, such as "Practical course on urological surgery and endoscopy". An extensive work on the subject of urinary retention and on diagnostic methods and procedures was written by Dr. Bernhard Neukirch, senior registrar of the surgical division of the Virgin Mary Hospital, which was run by the sisters of St. Charles Borromeo [11, 15, 26].

\section{The Academic School of Medicine in Gdańsk}

In 1945, with the end of World War II, as a result of the Potsdam Conference, Prussia was divided between Poland and the Soviet Union, and after its fall also between Lithuania, Latvia and Russia. And those borderlines have stayed the same to this day. The end of World War II created a new political situation in Europe. Danzig, nowadays Gdańsk, the West- and part of East Prussia region, became part of Poland. Germany was divided into East- and West Germany (until 1989/1990). Even before the end of World War II the Yalta Conference had agreed to place Danzig, under its original Polish name Gdańsk, under the de facto administration of Poland, and this decision was confirmed at the Potsdam Conference.

After the Soviet-German front had rolled through Danzig in 1945, with the associated hosts of refugees, immense destruction, looting, migration of peoples of diverse origin, and a period of anarchy, the buildings of the former Medizinische Akademie Danzig were taken over by the newly formed Polish Academy of Physicians, later renamed the Medical Academy of Gdańsk (Gdańska Akademia Medyczna-GAM). In 2009, GAM was again renamed the Medical University of Gdańsk (Gdański Uniwersytet Medyczny).

During the war the building of the Municipal Hospital in Danzig and other additional hospitals were spared, and immediately after the war were in use. Its rich material base, only partly destroyed, served as a foundation for its successor, the Polish Academy of Physicians of Gdańsk, which was set up there in a matter of three months, and opened on 15 October 1945.

Among the professors of the newly established college there were many eminent Polish scholars from the Polish University of Stefan Batory in Vilnius. They came to Gdańsk after Vilnius had been incorporated into the Soviet Union. Also a handful of scholars came from other pre-war Polish academic centres [3, 22, 23, 24]. 


\section{Urology in Gdańsk 1947-1971}

Urology has now existed in Gdańsk for 67 years. Its birth, its slow beginnings, and its long struggle for full autonomy and separation from surgery were laborious, difficult and a great strain. It was only the combination of political will towards change, the progressive view of the younger generation of surgeons, and the helpful attitude of the authorities of the GAM that finally brought about the creation of an independent Urology Clinic in Gdańsk, in 1971.

The first urological ward of 30 beds was set up in 1947, headed by a 41 -years-old urologist, Dr. Tadeusz Lorenz (1906-1986) - Figure 14 - from Lwów, now Lviv in the Ukraine. The ward was located in St. Mary's Hospital (Fig. 15), and existed within the Surgical Clinic until $1971[23,27,28,29,30]$.

Tadeusz Zygmunt Lorenz was born on 21 January 1906 in Drohobycz. He attended the Classical High School

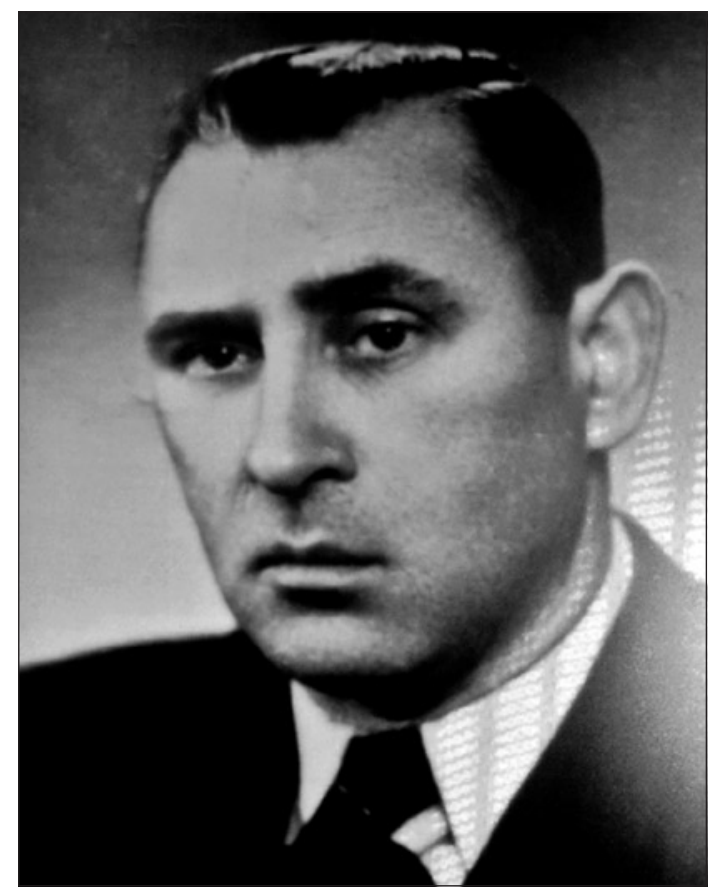

Fig. 14. Professor Tadeusz Lorenz (1906-1986)

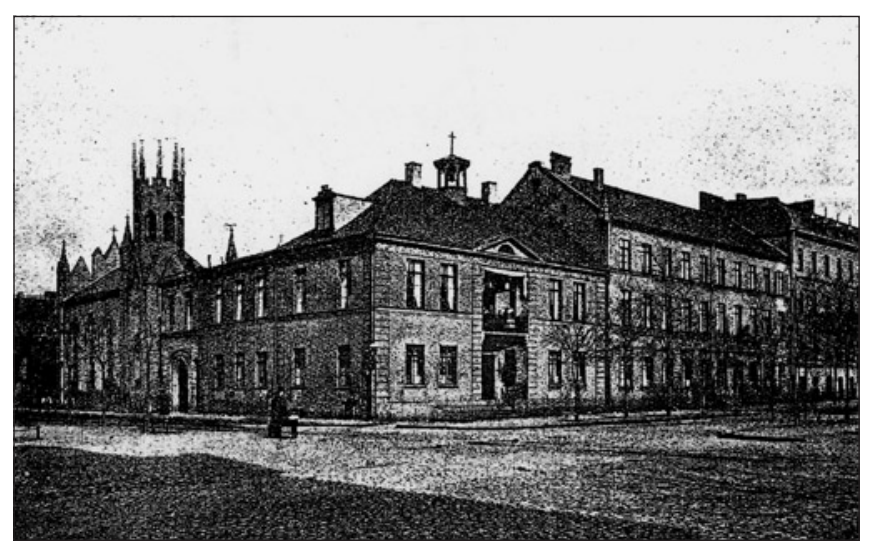

Fig. 15. St. Mary Hospital in Danzig in Stanisławów, where he attained a secondary school certificate, in 1926. Thereafter he enrolled with the University in Lwów (Lemberg) and graduated in 1933. He started his physician's work at St. Lazarus Hospital in Cracow at the Department Internal Diseases. In 1934 he returned to Lwów, and became an assistant (resident) at the Department of Obstetrics and Gynaecology Clinic of the University of Lemberg. In 1935 he began his urological residency in the Urological Department at the State General Hospital in Lwów (Head: Prof. Stanisław Laskownicki, 1892-1978). In 1938 he obtained a medical degree from the University of Lwów.

In November 1942 Dr. Tadeusz Lorenz, one of Professor Laskownicki's pupils, became Head of the Urology Department in Lwów, and he ran it until 20 July 1944. Then, he escaped from Lwów to Dąbrowa Tarnowska (south-eastern Poland), where he founded and ran a small urological ward at the District Hospital. Then Doctor Lorenz moved to Gdynia (Pomerania), where he established a urological ward at the Municipal Hospital and led it for one year.

In May 1947 a 30-bed Urological Ward was opened in Gdańsk, forming part of the First Surgical Clinic of the GAM and later on belonging to the Third Surgical Clinic (headed by Prof. Zdzislaw Kieturakis). The head doctor of the new urological ward was Dr. Tadeusz Lorenz.

On 10 October 1954 he qualified as a university lecturer with his postdoctoral thesis entitled "The influence of the estrogenic on the treatment of benign and maligned tumours of the prostate". In 1958 Docent Lorenz left Gdańsk and took over the Urological Clinic with 70 beds at the Medical Academy in Wrocław (Breslau) after Prof. Florian Nowacki (1902-1957). In this post he succeeded in all the stages of a full academic career in both science and administration. After the departure of Docent Lorenz in 1958, Dr. Jan Renkielski (1913-1996) was acting Head of the ward until 1971 (Fig. 16) [23, 26, 27, 28, 29, 31].

Jan Renkielski (Hartwig Jan Reinke) was born on 8 January 1913 in Kwidzyń (Marienwerder), south of Gdańsk. He finished his primary education in Tczew (Dirschau), and received his secondary school certificate there in 1932. In 1933 he enrolled at the University of Poznań, and graduated in 1939. In September 1939 Renkielski escaped to Garwolin ahead of the German forces. On returning home he was twice imprisoned by the Germans, although only for short periods.

In February 1940 he moved illegally to the General Government (an area of Poland occupied and administered by the Third Reich during the war). In Józefów, Puławy (south-east of Poland), he worked first as a GP and later as a Director of the Polish Red Cross Centre, and also as a doctor at the Common Insurance Company. From September 1945 until 31 December 1947 he took the academic curriculum at the Dental Clinic of GAM. On 12 November 1947 he was certified as a dentist. On 1 January 1948 he began his surgical training at the Surgical Clinic of the GAM. During this period he became a general surgeon (1952), and a full 
surgeon (1954). From 1950 to 1958 Doctor Renkielski was an assistant (resident) at the Urological Ward of the Surgical Clinic of the GAM (headed by Dr. Tadeusz Lorenz). On 18 October 1949 he changed his name from Hartwig Jan Reinke to a Polish name, Jan Renkielski. He became a urologist in 1958. After the departure of Docent Lorenz to Wrocław in 1958 Doctor Renkielski was acting Head of the Urology Department at the Third Surgical Clinic of GAM - until 1971. And it was during this time that he obtained his medical degree, in 1962.

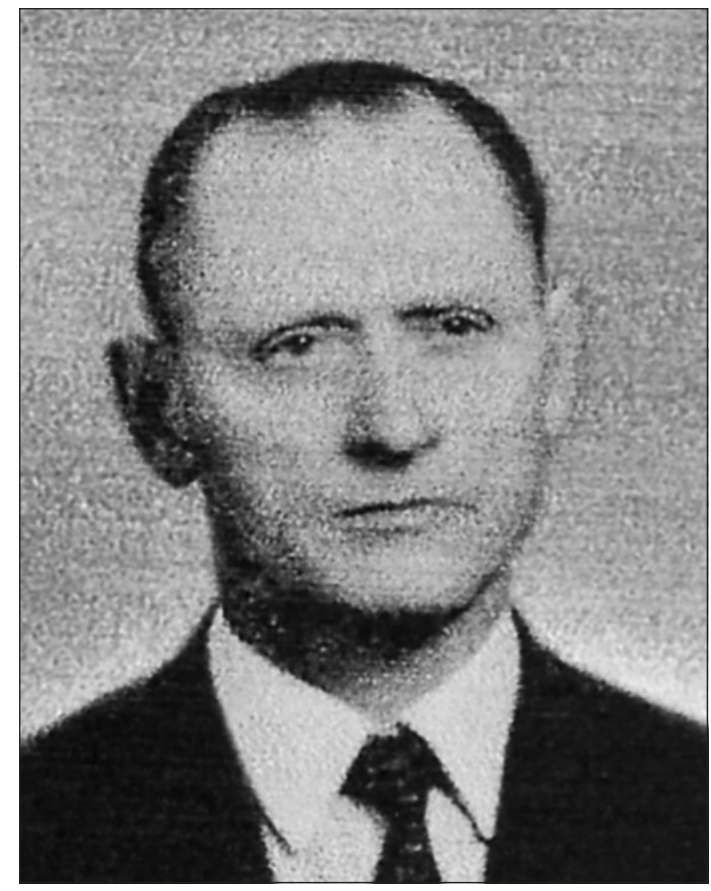

Fig. 16. Doctor Jan Renkielski (1913-1996)

The focus of his clinical activity was genitourinary surgery and ileo-cystoplasty (bladder augmentation). After leaving the Urology Department in 1971 he continued working at the Surgical Clinic at GAM as a senior lecturer. He authored 32 publications. He died in 1996 in Gdańsk.

Up until this time the ward had been an administrative unit of the Department of Surgery. Urology could not develop properly for it had no independence as a speciality. In the course of its existence the urological ward continuously shifted between various surgical clinics, and although it reached the medial level in terms of routine practice, it could not boast any important scientific activity [1, 3, 27, 28, 31, 32].

\section{The first independent Urology Department (from 1971)}

The present academic Urology Department with 39 beds (since 2012 only 24 beds) was founded on the basis of the urological ward 24 years before, in 1971. The urological department had been officially established as an independent unit, but again, within the framework of the general organisational restructuring which was taking place in Poland then. In 1971 the Urological Clinic was made part of the Surgical Institute, which had been founded in Gdańsk in 1970.

Its founder and first Head Physician was Prof. Kazimierz Adamkiewicz (1928-2004) from Zabrze (Hindenburg), Silesia (Fig. 17). With Adamkiewicz's leadership, almost all the contemporary diagnostic apparatus and therapeutic equipment and treatment methods of urological diseases at that time had been introduced for the improvement of the department. Under his supervision endourology (transurethral operations), percutaneous nephrolitholapaxy (PCN) uretero-renoscopy (URS), as well as surgical and chemotherapy of testicular tumours (connected with retroperitoneal lymphadectomy) were introduced and developed. Professor Adamkiewicz was also actively involved in the work of numerous scientific organisations. In 1973 Adamkiewicz was President and organizer of the $16^{\text {th }}$ Conference of the Polish Urology Association (PTU) in Gdańsk.

Kazimierz Adamkiewicz was born on 4 March 1928, in Chorzelany, Pszasnysz district, Mazovia, Poland. He graduated at the Medical Academy in Lublin, in 1952. From 1952 to 1957 he was an officer (finally with rank of major) of the special department of the Ministry of National Defence. During this time he began his surgical and urological training in Silesia. His teachers in surgery and urology were Professors A. Szczerbo, J. Gasiński, S. Szyszko and J. Zieliński. During this period he became a general surgeon (1956) and urologist, and obtained his medical degree from the Silesian Academy of Medicine in 1960. From 1963 Doctor Adamkiewicz headed a 40-bed urological ward at the Second Surgical Clinic in Zabrze. In 1967 he qualified as a university lecturer with his postdoctoral thesis entitled

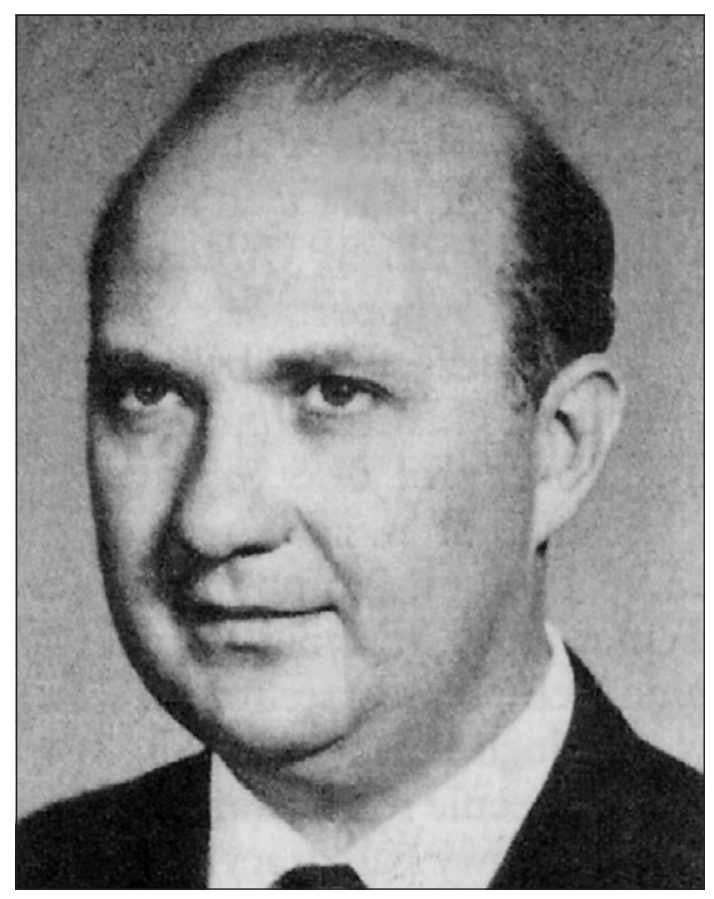

Fig. 17. Professor Kazimierz Adamkiewicz (1928-2004) 
"Analysis of hereditary hypospadias in men on the basis of cytogenetic testes and genealogy". Docent Adamkiewicz continued working at the unit until 1971. In 1971 he moved to Pomerania, where he became Head of the Urological Clinic, newly-established at the GAM. In 1978 he became Associate Professor, and in 1988 Full Professor.

Professor Adamkiewicz authored around 100 publications and conference papers. In 1986 he organised the $19^{\text {th }}$ Congress of PTU in Gdańsk. Unfortunately, he became ill and bedridden due to a stroke in 1988, at the zenith of his scientific productivity and his professional fame at the age of 60. Professor Adamkiewicz died after a long illness at the age of 74, on 26 August 2004.

After Professor Adamkiewicz retired from work due to his illness the department was managed for about two years by Professor Zbigniew Gruca, a surgeon (*1933), and from 1989 until 1991 by Docent Kazimierz Krajka. In 1991 Krajka was appointed a Professor, and until September 2012 he was a Head of the Urological Department (Fig. 18) [22, 27, 28, 29, 33].

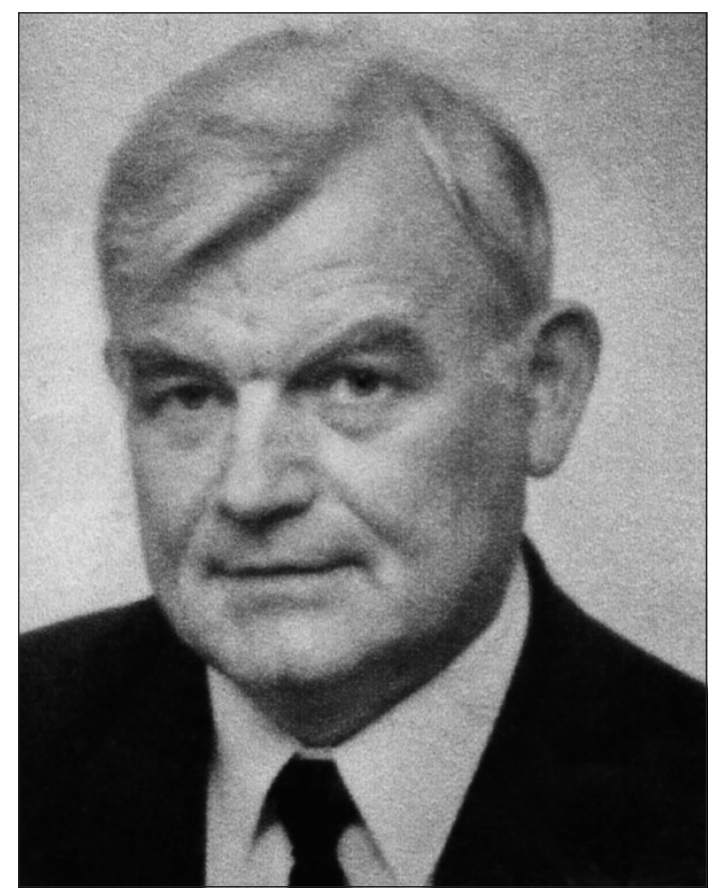

Fig. 18. Professor Kazimierz Krajka (*1941)

Kazimierz Krajka was born on 28 December 1941 in Nadratów, Mława (northeast Poland). He studied medicine at the GAM and graduated in 1965. He started his academic career as a resident in the Surgical Clinics of GAM, and obtained his medical degree from GAM in 1971. During this period he became a full surgeon (1973). He worked in Angola (1976-1977), and in Libya (1978-1980), and as a ship's doctor. On his return to Poland he worked as a surgeon in GAM. In 1987 he qualified as a university lecturer with his postdoctoral thesis entitled "My own method of herniotomy in patients with high risk of hernia relapse". In May 1989 the authorities at the Academy entrusted Docent Krajka with the post of Acting Head of the Department of
Urology, which he chaired until his retirement. He became an urologist in 1991. He underwent basic urological training as a postgraduate scholarship holder in Schwelm (Germany), and as a visiting physician at renowned clinics in Milan (Italy), Rennes (France) and Hamburg (Germany). He became a full Professor of Urology in 1999.

With Krajka's leadership, almost all the contemporary diagnostic apparatus and therapeutic equipment and treatment methods of urological diseases was introduced and developed. The focus of his clinical activity was operative urology, radical operations on patients with tumours of the urogenital system, and especially transsexual surgery (sex change of the male/female type).

He authored and co-authored over 200 scientific publications and congress reports. He is also the author of 26 scientific films, which have been shown many times at meetings in Poland and abroad. In recognition of his services in this field, Professor Krajka was appointed in 2001 to organise the $13^{\text {th }}$ Video Urology World Congress in Gdańsk. Professor Krajka chaired the organisational committee for the $25^{\text {th }}$ Conference of the PTU in 1995. He organized the $41^{\text {st }}$ Urological Congress of PTU in 2011. Professor Krajka retired in September 2012 [1, 3, 27, 28, 29, 34].

\section{Urology in Gdańsk today}

During its existence the Urological Ward in Gdańsk has changed its location several times. Nine years ago the University Department of Urology was relocated from St. Mary's Hospital to the Women's Hospital, with Professor Krajka as Head of the Urology Unit, with 39 beds. The Gdańsk Urological Clinic was located on the third floor of the Hospital for Women (until 1945 Frauenklinik und Provinzial Hebammen Lehranstalt, Langfuhr). This Women's Hospital Teaching School for Midwives has existed since 1819 (Fig. 19).

In March 2012 the Clinic of Urology of the Medical University of Gdańsk (MUG) was again relocated to the Academic Hospital Centre at Smoluchowskiego Street 17 (until 1945 Feldstrasse), in Gdańsk (Fig. 20).

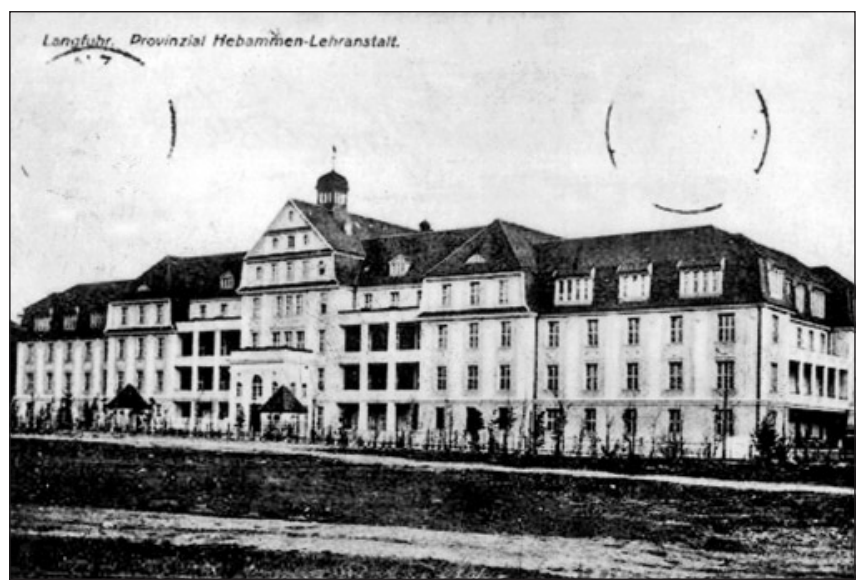

Fig. 19. Department of Urology in Gdańsk, third floor 


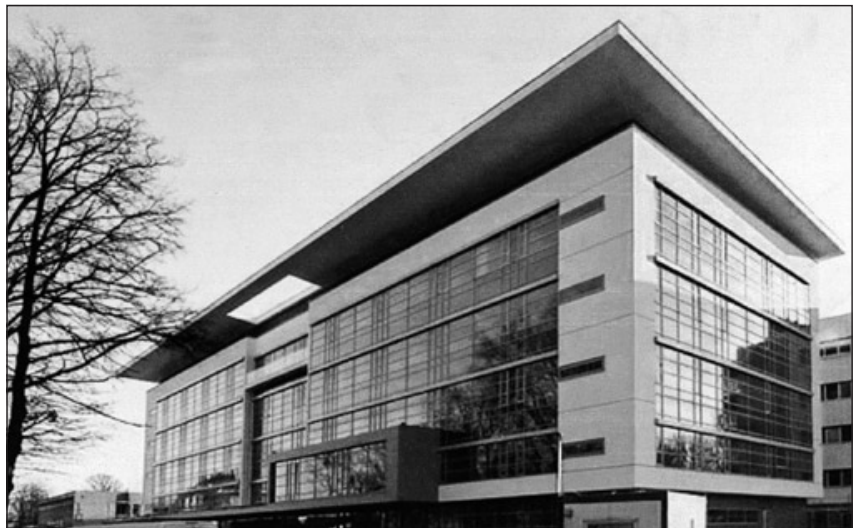

Fig. 20. The Academic Clinical Center in Gdańsk (2013)

Today the clinic has 24 urological beds. On 1 October 2012, Associate Professor (Docent) Marcin Matuszewski (*1965) was appointed head of the facility (Fig. 21).

Marcin Matuszewski was born on 31 October 1965. He attended the Classical High School, studying mathematics-physics, where he attained a secondary school certificate. Thereafter, he enrolled in the Medical Academy in Gdańsk

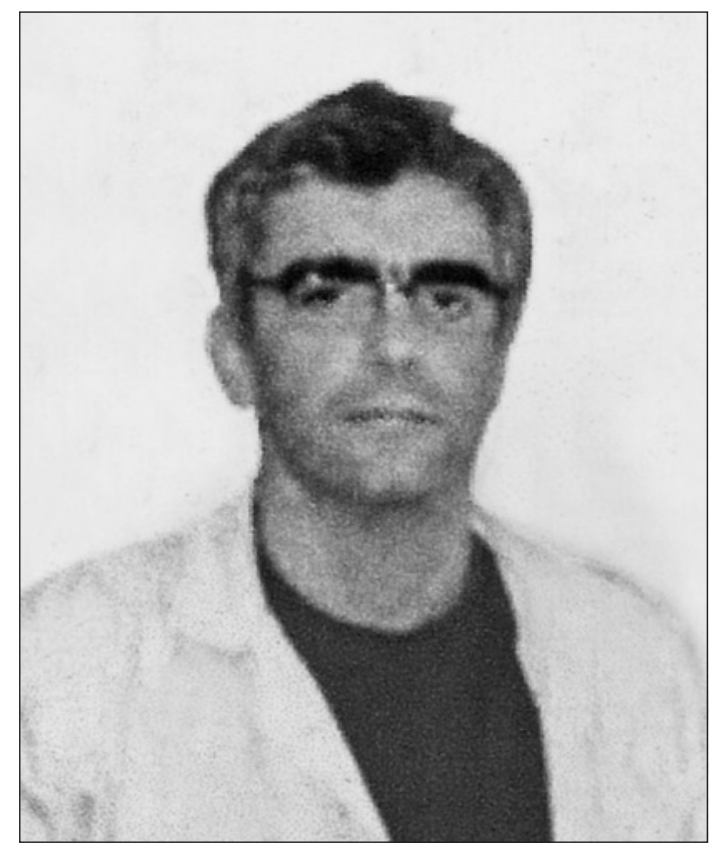

Fig. 21. Associate Professor Marcin Matuszewski (* 1965)

and graduated from the Academy of Medicine in 1991. He received his surgical and urological training in MUG and abroad (London, Copenhagen, Gainsville and Eastbourne) $[1,3,27,29,30,35,36]$.

\section{The Medical University of Gdańsk}

Today the Medical University of Gdańsk is the largest medical academic institution in northern Poland and teaches over 5,000 undergraduate and postgraduate students in 4 faculties.
In 2001 almost 60,000 patients were hospitalized there, over 21,000 of whom underwent surgery. Additionally, over 250,000 outpatient consultations were carried out.

Statistical data from 2011 showed the population of Gdańsk to be 455,830 .

Presently, in addition to the Urological Clinic, there are now other independent urological units in Gdańsk:

- The Department of Urology (34 beds) in the Specialist Hospital of St. Adalbert (Zaspa). J. Pawła II Street, under Dr. Arkadiusz Mikszewicz.

- Department of Urology in the Naval Hospital (11 beds), Polanki Street, headed by Dr. Jan Iwanicki, who also trains three residents in urology. Altogether, in 2012, there were 65 urological beds in different hospitals in Gdańsk [1, 3, 29, 35].

\section{References}

1. The Main Library and Archive of the Medical University of Gdańsk.

2. Zieliński J., Kopacz A., Świerblewski M.: The Development of the surgery in Gdańsk from 1454 to1945. Ann Acad Med Gedan. 2007, 37, 151-158.

3. Zajaczkowski T:: Education in medicine and surgery - Development of urology in Danzig/Gdańsk. In: De Historia Urol. Europ. Ed. D. Schultheiss. EAU, Arnhem 2011, 18, 49-78.

4. Scholz H., Schroeder P.: Ärzte in Ost- und Westpreußen. Leben und Leistung seit dem 18 Jahrhundert. Holzner, Würzburg 1970.

5. Ziegenhagen P.: Rückblick in die Danziger Medizingeschichte anlässlich der Eröffnung der Staatlichen Akademie für praktische Medizin in Danzig. Die Medizinische Welt. 1935, 9, 847-849.

6. Hirsch T:: Geschichte des Akademischen Gymnasiums in Danzig, in ihren Hauptzügen dargestellt. Wedelschen Hofbuchdruckerei, Danzig 1837.

7. Loth E.: Gdańska Szkoła Anatomiczna (1584-1812). I. Gimnazjum Gdańskie i ogólna charakterystyka szkoły lekarskiej. Arch Hist Filoz Med Hist Nauk Przyr. 1928, 8, 1-228.

8. Kulmus J.A.: Anatomische Tabellen Nebst dazu gehörigen Anmerkungen und Kupffern / Daraus des des ganzen Menschlichen Körpers. Beschaffenheit und Nutzen deutlich zu ersehen / Welche Den Anfängern der Anatomie zu bequemer Anleitung verfasset hat. Dritte Aufflage, Bey Corrnelius von Bughem, Danzig 1732.

9. Szarszewski A.: Johann Adam Kulmus, 'Tabullae Anatomicae', Danzig 1772. Sugita Genpaku. 'Kaitai Shonsho', Edo 1774. Ann Acad Med Gedan. 2009, 39, 133-144.

10. Sokót S.: Wędrowni operatorzy w Gdańsku (Wandering surgeons in Danzig) w XVI i XVII w. Ann Acad Med Gedan. 1958, 15-246.

11. Zajaczkowski T: Remembering Arthur Barth (1858-1927) - Towering achievements of a modest man. Eur Urol Today. 2013, 25 2, 25.

12. Sauerbruch E.F.: Zum 25 jährigen Jubiläum Arthur Barths als Chirurgischer Krankenhausdirektor in Danzig. Dtsch Z Chir. 1921, 166, 1.

13. Free City of Danzig. Wikipedia. http://en.wikipedia.org/wiki/Free City_of_Danzig-Wikipedia, the free encyclopedia (4.02.2013).

14. Schmidt A.: Die chirurgische Abteilung des Städtischen Krankenhauses in Danzig. Dtsch Z Chir. 1921, 166, 1-9.

15. Zajaczkowski T.: Remembering Heinrich Klose (1879-1968). First Professor of Academic Surgery in Danzig. Eur Urol Today. 2009, 21, $6,24$.

16. Klose H.: Lebensbilanz. Erinnerungen eines Chirurgen, der mehr als zwanzig Jahre in Danzig gewirkt hat. Aus der Medizingeschichte Ostund Westpreußens. 1963.

17. Mitzka H.: Prof. Dr. med. habil. Heinrich Klose (1879-1968). Porträt eines deutschen Chirurgen. Verlag und Antiquariat für Medizin W. Klose Bensheim-Auerbach, 1987. 
18. Büngeler $W$ : Die Neugegründete Staatliche Akademie für Praktische Medizinzum Danzig. Dtsch Med Wschr. 1935, 15-554.

19. Ziegenhagen P.: Die Medizinische Akademie in Danzig, ein Markstein im Zuge medizinisch-naturwissenschaftlicher Bestrebunden der Hansestadt. In: Medizinische Akademie in Danzig. Personal- und Vorlesungs-Verzeichnisse, Sommersemwster 1941, Wintersemester 1941/42. 1941, 3-18.

20. Behrendt P.: Die Kriegschirurgie von 1939-1945 aus der Sicht der Beratender Chirurgen des deutschen Heeres in Zweiten Weltkrieg Inaugural-Dissertation: Universität Freiburg im Breisgau, 2003.

21. Gustloff: Cruise in den Tod. Stern. www.stern.de/politik/geschichte/ wilhelm-gustlofffahrt-in-die katastrophe-5363 (4.02.2013).

22. Bilikiewicz A., Bilikiewicz M.: Jubiläum der Medizinischen Akademie in Danzig. 60 oder 70 Jahren von der Medizinischen Akademie in Danzig. Gazeta AMG. 2005, 15 (4), 31-35.

23. Żydowo M.: Jubileusz Akademii Medycznej w Gdańsku. 70. rocznica powołania pierwszej akademickiej uczelni w Gdańsku. Gazeta AMG. 2005, 15 (4 and 10), 40-42.

24. Żydowo M., Bukowski M.: Jubiläum der Medizinischen Akademie in Danzig. 60. oder 70. Jahren von der Medizinischen Akademie in Danzig. Gazeta AMG. 2005, 15 (4).

25. Imieliński B.L.: Czym była w istocie i jaki kształt organizacyjny miała poprzedniczka naszej uczelni. Medizinische Akademie in Danzig (MAD)? Gazeta AMG. 1995, 11, (5/59), 11-12.

26. Neukirch B.: Rückstaungsniere. Die Medizinische Welt. 1935, 20, 43-47.
27. Krajka K.: Katedra i klinika urologii. 50 lat Akademii Medycznej w Gdańsku. Ann Acad Med Gedan. 1995, 25, Suppl. 1, 233-239.

28. Stachurski L.: Urologia. In: Historia chirurgii, dyscyplin zabiegowych i anestezjologii Gdńska i regionu gdańskiego. Sympozjum Naukowe, 20 maja 1989 r. Pamiętnik. Ed. Z. Wajda. Tow. Chir. Pol. Gdańsk 1989, 90-95.

29. Stachurski L., Sprogis J., Sikorski A.: The development of urology in North-West of Poland. In: 50-years of the Polish Urological Association. Ed. A. Borkowski. Remedy, Warszawa 2003, Vol. I-II.

30. Steffen F.: Geschichte des St. Marien-Krankenhauses und des mit ihm verbundenen katholischen Mädchenweisenhauses Danzigs. Festschrift zum 75-jährigen Bestehen 1852-1927. Danzig 1927.

31. Zajaczkowski T.: Dr med. Jan Renkielski (1913-1996) (do 1949 r. jako Hartwig Jan Reinke). Prz Urol. 2011, 21, 1 (65), 82-84.

32. Kossak J.: Dr med. Jan Renkielski (1913-1996). Prz Chir. 1997, 69, 8, 880-881.

33. Drożyńska-Duklas M., Kamiński Z.: Adamkiewicz Kazimierz (19282004). In: Ludzie Akademii Medycznej w Gdańsku. Ed. Z. Machaliński. Akademia Medyczna w Gdańsku, Dział Wydawnictw AMG, Gdańsk 2005, 3-10.

34. Nowi profesorowie tytularni. Gdańska Akademia Medyczna. Prof. dr hab. Kazimierz Krajka. Gazeta AMG. 2000, 10 (5).

35. Medical University of Gdańsk. www.mug.edu.pl/1496html (4.02.2013).

36. Skarbek M.: Dlaczego wybrali urologię? Dr hab. n. med. Marcin Matuszewski, FEBU, Klinika Urologii, Gdański Uniwersytet Medyczny. Prz Urol. 2011, 6 (70), 37-43. 